УДК: 7.01

ББК: 85.110

A43

DOI: $10.18688 / \mathrm{aa} 177-7-63$

Jiří Tourek

\title{
Phenomenological Theory and a New Look at Continuity in Architecture ${ }^{1}$
}

Today most architects, urban planners and theorists believe that history is something valuable, something that is a part of our world and what we have inherited from it should be cherished. The protection of monuments and sites and the protection of ever younger pieces of architecture has become an important issue to which a lot of attention is paid. There are countless examples of it in the world. International attention was, for instance, attracted by the effort to enlarge and to rebuild Whitney Museum of American Art in NYC by Marcel Breuer. In the end, the museum found a new location and a new building was erected after the project by Renzo Piano. The context of the old building was considered so valuable that it could not be changed as the museum needed. The old Whitney building found a new purpose under the wings of MET museum. Even greater emotions aroused in the case of the American Folk Art Museum and its new building by Tod Williams Billie Tsien Architects built in 2001, also in New York. The decision to demolish the building provoked great displeasure although the building was only 13 years old and the number of visitors was smaller than expected. The similar although not identical cases are the re-construction of The Frauenkirche, in Dresden, or Berliner Stadtschloss, city palace in Berlin.

But it was not always the case in modern times. In the first half of the $20^{\text {th }}$ century, the situation was seen differently. The protagonists of modern architecture - although never united as we know today - were, nevertheless, generally not much interested in history of architecture. There were many positions from those claiming a radical break from tradition to many various expressing disregard to history, tradition and historical buildings to some that were simply not interested in history. Old cities, and especially $19^{\text {th }}$ century large cities, were generally considered as roots of all evil. All the leading protagonists took more or less some of these ideas. All this was still valid after the WWII. The post-war reconstruction of Europe was a good example. There is no need to discuss it more; the history of modern architecture has been mapped in detail.

Starting with the next generation this attitude began to change. The important proponents of these changes were to a large extent architects later associated with postmodern architecture (however, they didn't called it this way). In Robert Venturi's famous first book Complexity and

1 This publication was supported by The Ministry of Education, Youth and Sports - Institutional Support for Long-term Development of Research Organizations - Charles University, Faculty of Humanities (Charles Univ, Fac Human 2016). 
Contradiction in Architecture [12], the examples of baroque, rococo, and generally historical architecture played an important role. Postmodern architecture was "learning from" history. From this point roughly, our contemporary situation began to develop.

Approximately, the same generation as Robert Venturi was Christian Norberg-Schulz (1926-2000), a person most associated with the phenomenology of architecture, which he started to construct in his book Existence, Space and Architecture, first published in 1971 [5], and which found its fullest expression probably in his book Genius Loci of 1980 [6].

The phenomenology of architecture changed the architectural discourse in many ways, both for its admirers and followers and for those who did not accept, study, or follow it. Although it has never been the real mainstream, it pervaded permanently the world of architecture. Now, in the context of this text, the fundamental change is that from the very beginning there was history present. History was an important part of his theories. Many historical examples are already involved in his first book Intentions of Architecture [7].

Norberg-Schulz's interest in history was, nevertheless, no interest of (art) historians ${ }^{2}$, he did not write in terms of the history of styles (gothic, renaissance, baroque...). He constructed the history of existential meanings since he claimed for architecture an important role as an "existential foothold" [6]. History is now understood as an unbroken continuum of our human - relation to the world. This could be well observed in his book Meaning in Western Architecture [9] where he followed the changes in architecture from Ancient Egypt to his time and, though particular chapters bear names such as "Renaissance architecture" or "Mannerist architecture", it is not just an art history book. What he investigated there is how people relate to the world through architecture. How we interpret the world, particularly historical moments, and how afterwards architecture helps us live in existential terms. Thanks to this attitude there are countless examples of historical places, cities, monuments that are still valid because the basic human situations are always the same. Of course we no longer construct pyramids to bury our rulers, but the huge central mass of masonry (stone or other material), as a typical pyramid is, can - according to him - serve as the focal point of a community, as, for example, the tall dome of Santa Maria del Fiore over the city of Florence, or The National Congress building in the axis of the city of Brasilia.

In contrast to the fact that modernism generally understood itself as a break from the tradition, Norberg-Schulz re-established continuity in architecture since both modern and pre-modern architecture should provide what he called an existential foothold [6]. Modern and historical architecture is united by the same basis. This could be seen in his book Existence, Space and Architecture when he speaks of architectural space; the explication of the topic is built on examples from antiquity up to the modern times, but also in the book Genius loci when genius loci is discussed, the spirit of a place, the continuing character of a landscape, a settlement, a city, a building, a place, or a room. The logic is based on slightly changing but lasting continuity of the character of the built environment. To this I would like to make a remark: today, in the $3^{\text {rd }}$ millennium, we take for granted the value of history, old towns and of places, but in the 1960s and 1970s the situation was different. It was still possible to unmercifully demolish

2 Christian Norberg-Schulz is of course well known also as a historian. He wrote a book on famous Czech baroque architect Kilian Ignaz Dientzenhofer and two volumes of history of baroque architecture. 
historical buildings in an inner city to make a room for what was seen as an urban improvement. Architects, theoreticians, and urban planners as well believed they could or even should do it. Norberg-Schulz was among those who contributed to the change in the attitude.

His theories became, maybe unintentionally, the kind of theoretical justification for the transformation of the relationship with the past. Many such changes could be seen as positive. Architects can once again take inspiration from history: all human experience sedimented in centuries of built environment is open for them; we all newly learned to appreciate old and historical built environment, our old cities and towns. A position gradually appeared claiming with theoretic base - that everything new is not automatically and necessarily better than the old. If genius loci "is contained" in old things and buildings within the city, then suddenly we feel it is necessary to protect such sites. And not only protect, all new architecture has to respect the context of such places. Thus, we have a theoretical justification of contextualism. It all could hardly be seen otherwise than positive.

And not only this, since all this is possible without being necessarily caught up with historicisms. One of the key troubles that architecture had with the historical inspiration during the $19^{\text {th }}$ and early $20^{\text {th }}$ centuries were historicisms, gothic revival, and other "neo-styles." Learning from history could since now no longer be only stylistic. As mentioned above, Norberg-Schulz is not interested in history of styles, but in changing attitude toward the world through architecture and so the inspirations are on a different - someone might say on deeper - level than the style is. This distinguishes his position from postmodern architects and theoreticians (especially in later stage of postmodern architecture in the 1980s and later when postmodern architecture developed mostly into historical pastiche) and from so called modern classicists who exploit the classical language of architecture. Despite some interfaces with postmodernism in architecture, Norberg-Schulz cannot be considered a postmodernist, at least in the strict sense of the word $[10 ; 11]$. This does not change even the fact that he was interested in and an admirer of the works of Robert Venturi, the father of postmodern architecture, and other postmodern architects.

Every coin has two sides and the phenomenology of architecture as a kind of theoretical base for thinking of architecture also gradually resulted - at least in some part of (architectural) world - into the justification of the overcautious guarding of the historical heritage of our once again valuable old cities and historical places. What is generally seen as being positive, as mentioned above, the prepared positions, from which it is possible to theoretically justify the development of the last few decades of our present. Whatever the cause may be, the fact is that in last decades there has occurred in the West ever increasing interest in historical architecture and places, but not the interest of historians, but the interest rising from the society of uncertainty to protect the world as this society knows it. The Western civilization seems to appreciate its status quo more and more. What was in the days of Norberg-Schulz, in the 1970s or 1980s, the beneficial interest in historic buildings - as a way of inspiration and learning - turns today to preoccupation with history and preservation and sometime even in the form verging on an attempt of keeping the status quo. In cities like Prague, the situation is already on the way of the whole inner city becoming almost "untouchable". The situation has already provoked some theoretical thoughts. Among those with the greatest reach was Rem Koolhaas' lecture and follow-up book Preservation Is Overtaking Us [3]. 
A very interesting example is a case of The Libeñ bridge in Prague built in 1928 by the famous Czech early modern architect Pavel Janák (1882-1956) in collaboration with the architect and specialist on bridges František Mencl [2, p. 87]. The modernist bridge (with cubist features) was built of concrete. But unfortunately (because it is important for a future development), it was not built of traditional reinforced concrete but by the experimental technique of reinforced beated concrete. After circa seven decades of use the bridge was in bad technical condition, and experts suggested that the bridge should be rebuilt or replaced. A significant reaction both from citizens of Prague and from the preservationists (but from architects as well) changed the future destiny of the bridge. There suddenly occurred a common-interest association called Libeňský most nebourat, nerozšiřovat (Do not demolish, do not expand The Libeň Bridge) [4; 1]. An argument made by experts that to construct a brand new bridge would be much cheaper was not strong enough and was not accepted and plans are now in progress for reconstruction. A very important fact is that the bridge is not among the central bridges in the old city; it is located north of centre and is not anyhow connected with the "Prague identity". The significant reason for attempts by Prague public to preserve the bridge is the fact that it was already built - locals are used to it - and that's why the bridge should be protected: it is already there, should be there forever. How different is today attitude from the approach used just few decades ago when technical utilitarian constructions - as bridges or railway lines - were simply replaced at the end of their lifetime. A chance to have new (and may be more beautiful or more functional) bridge was not even in the air.

As a small curiosity it can be mentioned that among the arguments there was also "the protection of local genius loci."

This all is a sign of changed attitude. Large parts of the society, including architects, more and more tend to prefer protection and hinder large changes in cities and towns. All big transformations seem to be unwelcomed. It seems that for many the old was more desirable than the new, as if the future was seen as dangerous and unwelcomed. In some cases it has reached so far to protect the all status quo. The attempt to protect by a proposed but not yet approved regulation the urban skyline of Prague from all high rises not only within the city centre (what everyone would understand), but also in all locations visible from every point within city centre was very significant. It means that high rises would be possible only in the outer parts of the city. La Défance would not be possible under this edict.

In some parts of the western civilization, particularly in Western Europe, there is no longer much optimism about future, what come and what could come (and it has nothing to do with immediate political situation in one or other country). It is a symptom of our time. Norberg-Schulz's phenomenological theories are not the cause of all those changes. They are only in approximate coincidence with this entire move, but more importantly, they seem to help justify these processes - at least for part of architects, theoreticians, and preservationists. Although in many prestigious universities in the United States and in the UK, Norberg-Schulz is an abandoned and even forgotten author, he acted for a long time and in many central or east European countries his books are still effective up today. Everywhere he has fuelled an interest in identity (through the concept of genius loci for instance) and in historical architecture and places as a valuable part of our world and as an existential foothold. The phenomenologically built theories of Norberg-Schulz thus have rather ambivalent legacy. They helped to reopen history for us, but 
doing this they helped, probably unconsciously, to justify the present, often nostalgic attitude toward the world. And it is necessary to understand this. I consider the phenomenology in architecture as an ongoing project which may potentially have bright future, we should take it all into account.

\section{References}

1. Bečková K. Zachraňme Libeňský most..., podruhé. Věstník Klubu za starou Prahu, 2015, 3, pp. 13-16 (in Czech).

2. Kiesling N. Pavel Janák. Praha, Arbor Vitae Publ., 2011. 319 p.

3. Koolhaas R. Preservation is Overtaking Us. New York, GSAPP Publ., 2014. 104 p.

4. Libeňský most Nebourat, Nerozšiřovat. Available at: https://cs-cz.facebook.com/libenskymost/ (accessed 30 January 2017).

5. Norberg-Schulz Ch. Existence, Space and Architecture. London, Studio Vista Limited Publ., 1971. 120 p.

6. Norberg-Schulz Ch. Genius Loci. Towards a Phenomenology of Architecture. New York, Rizzoli Publ., 1980. $213 \mathrm{p}$.

7. Norberg-Schulz Ch. Intentions in Architecture. Cambridge, Massachusetts, MIT Press Publ., 1965. 242 p.

8. Norberg-Schulz Ch. The Concept of Dwelling. New York, Electa/Rizzoli Publ., 1985. 140 p.

9. Norberg-Schulz Ch. Meaning in Western Architecture. London, Studio Vista Publ., 1976. 236 p.

10. Otero-Pailos J. Architectural Phenomenology and the Rise of the Postmodern. The SAGE Handbook of Architectural Theory. London, SAGE Publ., 2012, pp. 136-151.

11. Otero-Pailos J. Photo[historio]graphy. Christian Norberg-Schulz's Demotion of Textual History. An Eye for Place. Christian Norberg-Schulz: Architect, Historian and Editor. Oslo, Akademiks Publ., 2009, pp. 62-94.

12. Venturi R. Complexity and Contradiction in Architecture. New York, MoMa Publ., 1966. 136 p.

Title. Phenomenological Theory and a New Look at Continuity in Architecture.

Author. Jiř́ Tourek - Ph. D., assistant professor. Charles University, U Kř́žže 8, 15800 Prague 5, Czech Republic.tourek@gmail.com

Abstract. In the second half of the $20^{\text {th }}$ century, there occurred a gradual but profound change in the view of history in the architectural world. The generation active in post war time (among others Mies van der Rohe) mainly neglected the history of architecture. Starting with the next generation, this attitude radically changed. The important proponents of these changes were to a large extent the architects that were later associated with postmodern architecture. All this is well known.

Less known is the role that was played by phenomenology in architecture as a theoretical ground of this change. The article is focused, through an example of Norberg-Schulz's theories, on the transformation of interest in the history of architecture and on the new understanding of continuity in architecture.

What is generally seen as an achievement, i.e. the newly established relation to historical architecture and to built environment, the re-established possibility of inspiration in history, tradition, and continuity without being necessarily got caught in various historicisms etc., has, nevertheless, the other side. This other side is the preoccupation with history, the obsession to maintain the status quo of all built environment, the increase in preservation, which can all be observed in large parts of the western civilisation. Thus, the article aims to explore the ambivalent legacy - in terms of relation to history - of some of the phenomenological theories in architecture.

Keywords: phenomenology; architecture; theory; Norberg-Schulz; modernity; preservation.

Название статьи. Феноменологическая теория и новый взгляд на непрерывность в архитектуре.

Сведения об авторе. Тоурек, Иржи - Ph. D., доцент. Карлов университет, У Кржице, 8, Прага 5, Чехия,158 00. tourek@gmail.com

Аннотация. Во второй половине XX в. свершился постепенный, но глубокий перелом в отношении архитекторов к истории архитектуры. Старое поколение, работавшее в послевоенные годы (в числе прочих и Мис ван дер Рое), по-прежнему игнорировало ее. Это отношение радикально изменило новое поколение. Главная роль принадлежала архитекторам, которые позже проявят себя как представители постмодернизма. Все это хорошо известно. 
Меньше внимания было уделено значению феноменологии в качестве теоретической основы, подготовившей такой пересмотр позиций.

Цель настоящей статьи - продемонстрировать на примере теории Норберга-Шульца трансформацию интереса к истории архитектуры и новое понимание непрерывности в архитектуре.

То, что традиционно считается достижением, - формирование новой связи с архитектурой предшествующих периодов, создание архитектурной среды, вновь открытая возможность обрести вдохновение в истории, традиции, непрерывность, которая может осуществляться без непременного соскальзывания в различные «историзмы», - имеет и обратную сторону. Она выражается прежде всего в чрезмерной озабоченности вопросами истории, одержимости идеей соблюдения status quo архитектурного окружения, тотальной консервации, которые можно наблюдать в разных сферах западной цивилизации.

Таким образом, статья посвящена рассмотрению вопроса об амбивалентности наследия в его взаимосвязи с историей в некоторых феноменологических теориях архитектуры.

Ключевые слова: феноменология; архитектура; теория; Норберг-Шульц; модернизм; консервация. 